\title{
ECOLOGICAL RISK ASSESSMENT IN THE FUNCTION OF ENVIRONMENTAL PROTECTION
}

\author{
Saša T. Bakrač, Army of Serbia, Military Geographical \\ Institute, Belgrade, \\ Miško M. Milanović, University of Belgrade, \\ Faculty of Geography, Belgrade, \\ Mirjana J. Marić, Ministry of Agriculture, Trade, Forestry and \\ Water Management, of the Republic of Serbia \\ Srđan S. Marković, Ministry of Defence of the Republic \\ of Serbia, Department for General Logistics, Belgrade
}

FIELD: Earth Sciences

DOI: 10.5937/vojtehg1204165B

ARTICLE TYPE: Professional Paper

\section{Summary:}

This paper proposes an appropriate methodology for ecological risk assessment. The methodology has been applied in the region of Boka Kotorska Bay (Bay), Montenegro.

The emphasis of the research is on the analysis of the impact of various stressors on the ecological components of Bay. The consequences of that impact can be seen in an increased level of eutrophication of water environment, mostly through the influence of nitrogen and its compounds.

The actual research at/about the region of Boka Kotorska Bay was performed in the period of 2008.

The study emphasized the importance of the acquisition, processing and analysis of various ecologically related data for more efficient monitoring and management of the environment.

The suggested methodology of the ecological risk assessment is, therefore, a remarkable scientific and expert contribution in the area of environmental protection in our country and in general.

Key words: risk management, ecological risk assessment, stressor, pollution, eutrophication.

\section{Introduction}

Unlimited industrial growth, as opposed to limited resources of an ecosystem, inevitably leads to environmental degradation. This impact can especially be seen in the ecosystems and in the areas with signifi- 
cant human population, as it is the case in Boka Kotorska Bay. The research showed that using a proper ecological risk assessment methodology, as the one described in this paper, it is possible to assess that impact correctly and manage the ecological risk in order to reduce the effects of pollution.

Using the acquired facts and scientific knowledge from this scope as well as from managing projects [2], we developed a specific assessment model that can serve as a good basis for future assessments. Assuming that the increase of nitrogen salts is one of the most significant causes of the problems in the aquatic environment (caused by the anthropogenic factor), such as the reduction of the population of some sea grass species, this risk assessment estimates and models the effects of these substances (compounds) on significant ecological resources. It is thus shown that the increased concentration of these substances is an alarming stressor ${ }^{1}$ in the Boka Kotorska Bay area.

Using the documented analysis processes and models applied in similar research projects, we came to a method that can be used to assess the risk of increased concentrations of nitrates and nitrites in the environment, as well as to determine the extent of these problems compared to other stressors.

\section{Research Program}

According to its definition "ecological risk assessment is a process to collect, organize, analyze, and present scientific information to improve the use of science in decision making" [12], leading to creation and adoption of necessary policies that ensure environmental protection and improvement of the ecological situation in an area.

The assessment model developed by the U.S. EPA (Figure 1) was used as the methodology framework for this research. According to the methodology used, the risk assessment included the preparation process - planning - and three research phases (problem formulation, analysis and risk characterization).

\section{Assessment planning}

The methodology of ecological risk assessment necessarily requires a clear separation of the planning process from the assessment process [13]. In fact, in the planning process, in the scope of the problem formulation phase, we try to define the environmental and socio-economic key points, as well as to develop the necessary conceptual models and plans for the risk analysis. In this case, the assessment of ecological risks of Boka Kotorska Bay (in further

\footnotetext{
${ }^{1}$ The term "stressor" means any physical, chemical or biological entity that can cause - and often induces negative and less positive reactions. Read more, see: U.S. Environmental Protection Agency [14].
} 
text: the Bay) is planned to be developed using the appropriate risk analysis model - model of increasing eutrophication (MIE) - which will serve to predict the impact of primary stressors on the given key points.

In addition to that, in the scope of planning activities, the objective of the assessment was clearly defined as: "The establishment and maintenance of water quality and habitat conditions in the Bay, in order to:

a) ensure the survival of different populations of plant and animal species that live in the Bay water, and

b) suspend the process of degradation of the ecological resources in the Bay area.

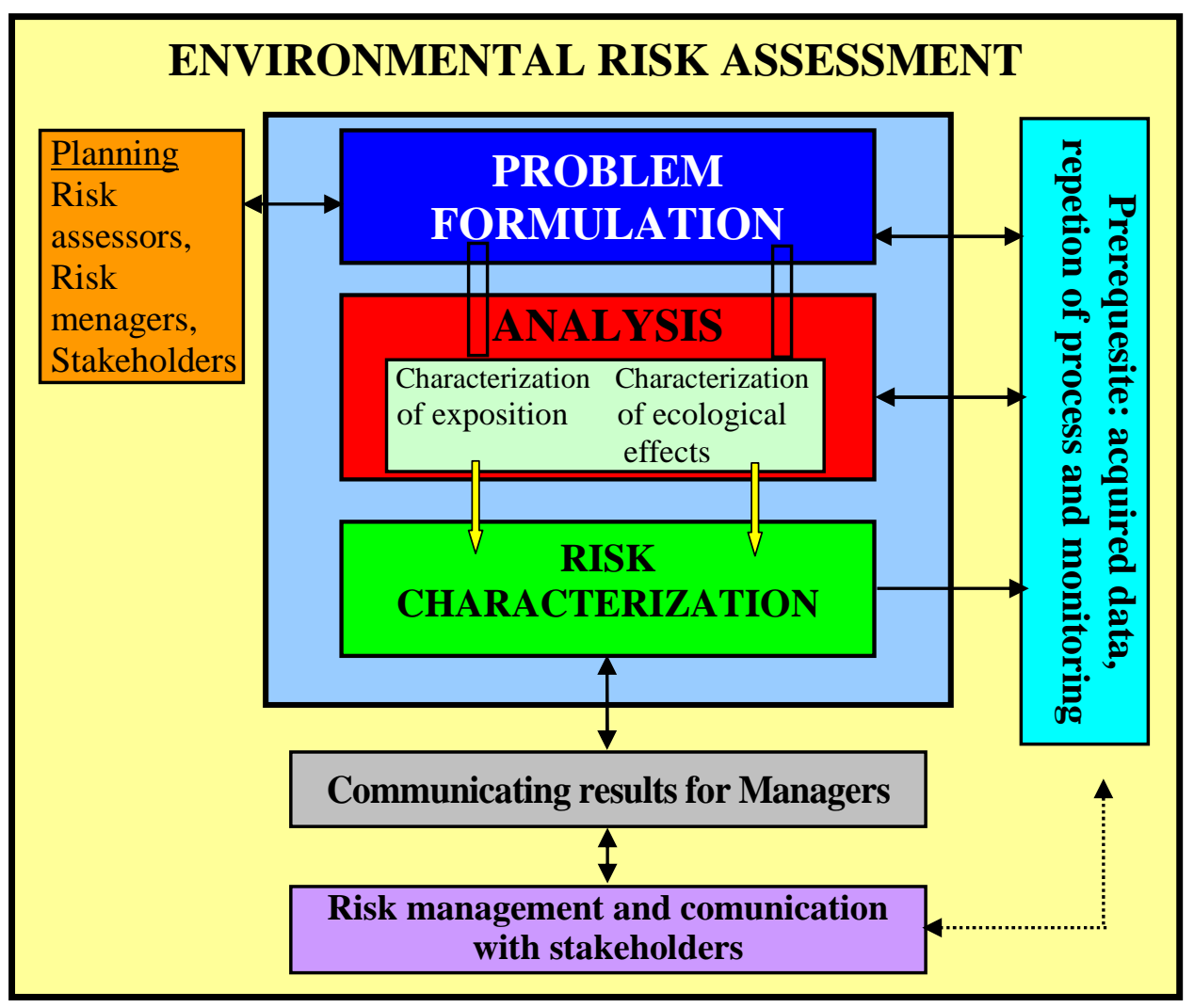

Figure 1 - Simplified schematic view of the average assessment of ecological risk (U. S. EPA,1998).

Slika 1 - Šema: prikaz prosečne procene ekološkog rizika (U. S. EPA,1998)

In the scope of planning this risk assessment, we defined the following: aim and objectives of management, purpose of managing and scope and complexity of appraisal. 


\section{Problem Formulation}

The problem formulation, as the scientific part of the ecological risk assessment of the Bay, includes the definition and selection of dominant stressors, as well as the choice of assessment key points and the development of conceptual models [15].

The conceptual model of the Bay (Figure 2) is the most important result of this phase of the evaluation and, in the opinion of many authors, the most important segment of the overall process of the assessment. [6]. While that conceptual model is similar to other well-known models in terms of methodological approach being used, its contents and the information it provides is unique and specific for the given area.

Having in mind that no historical data were available on the environmental state of the investigated area, based on a unique environmental risk assessment methodology (as it is the with some well-known risk assessments described in the literature), the assessment model was designed to use some assumed information/data as well.

\section{Risk Analysis}

This phase comprises the necessary measurements and the analysis of the exposure degree of selected assessment key points and related environmental effects, according to a given stressor. The risk analysis phase was specific in the terms of the euthrophication assessment model (EAM) that was developed, according to the decisions made in the planning phase. This model is specific for its role in the risk assessment of the investigated area, since it was used to estimate its exposure to coastal eutrophication, by measuring the increment of total nitrogen and the concentration of nitrogen salts (nitrates and nitrites) deposited in the water of the Bay. This model is also specific because there was no history of monitoring of this phenomenon, so estimated values had to be modeled. Hence, the results achieved by this model are relevant to the Bay region, but also to other similar bay areas which lack resources (funding and data).

Taking the samples of the coastal sea water (Figure 3) was done on 20 locations (5 in each) in four smaller bays (Tivatski, Kotorski, Risanski and Hercegnovski Bay), four times during the year (one Spring sampling, two Summer and one Autumn). The analyses were conducted at the Institute for Health of the Republic of Serbia (nitrates and nitrites - Figure 4). In the process of creation of the EAM model and the formulation of standards we modeled the estimated total nitrogen inputs, as well as the estimated concentrations of nitrates and nitrites in the Bay water, using the results of similar analyses described in the literature. The values described in the literature served as a reference, to compare them to the valu- 
es estimated by our model, in order to confirm the acceptability of the model, determine the degree of its unreliability and make some predictions based on the obtained evaluation results.

The research results obtained in this phase confirmed the presence of increased concentrations of nitrates and nitrites in the sea water (in the coastal belt) in the whole Bay area, with clearly defined zones (parts of the Bay) having the largest concentrations of these substances. It is believed that the concentration of nitrates and nitrites, which also depends on other factors (water temperature, influx of fresh water, etc.), has the greatest impact on the eutrophication level. [9]. Because of that, there is a high degree of certainty that concentrations of nitrates and nitrites are strongly correlated to the level of eutrophication.

The results indicate that the increased (excessive) concentrations of nitrates and nitrites occur mostly during summer, in the inner parts of the Bay and that they decrease in the later summer periods. This phenomenon is also related to the human population in the area during the observed periods of time.

The measured mean annual concentrations of nitrates and nitrites give a clear picture of the total level of eutrophication in the coastal areas of the Bay, giving us the possibility to estimate the level of eutrophication of more distant coastal zones.

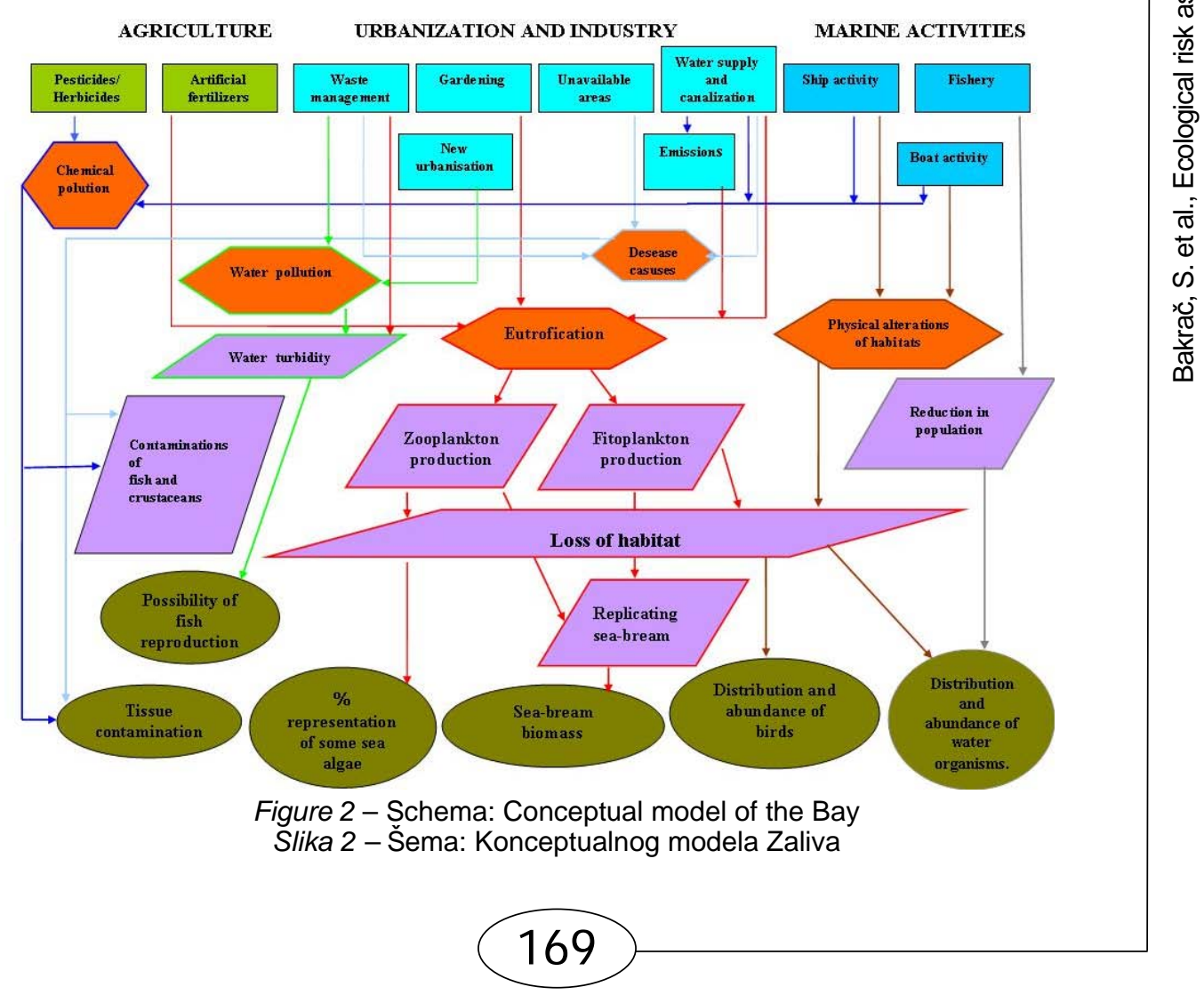


Agriculture, urban development, industry and marine activities are here seen as major sources of pollution. Recognized stressors are defined through chemical and water pollution, physical alteration of habitats, eutrophication process and disease causes. The effects to the ecosystem are: changes in water turbidity; loss of habitat; changes in zooplankton and phytoplankton production; reduction in population; replicating sea-bream and contaminations in fish and crustaceans. The key points observed are: tissue contaminations; percentage of representation of some sea algae; sea-bream biomass; distribution and abundance of birds; distribution and abundance of water organisms and possibility of fish reproduction.

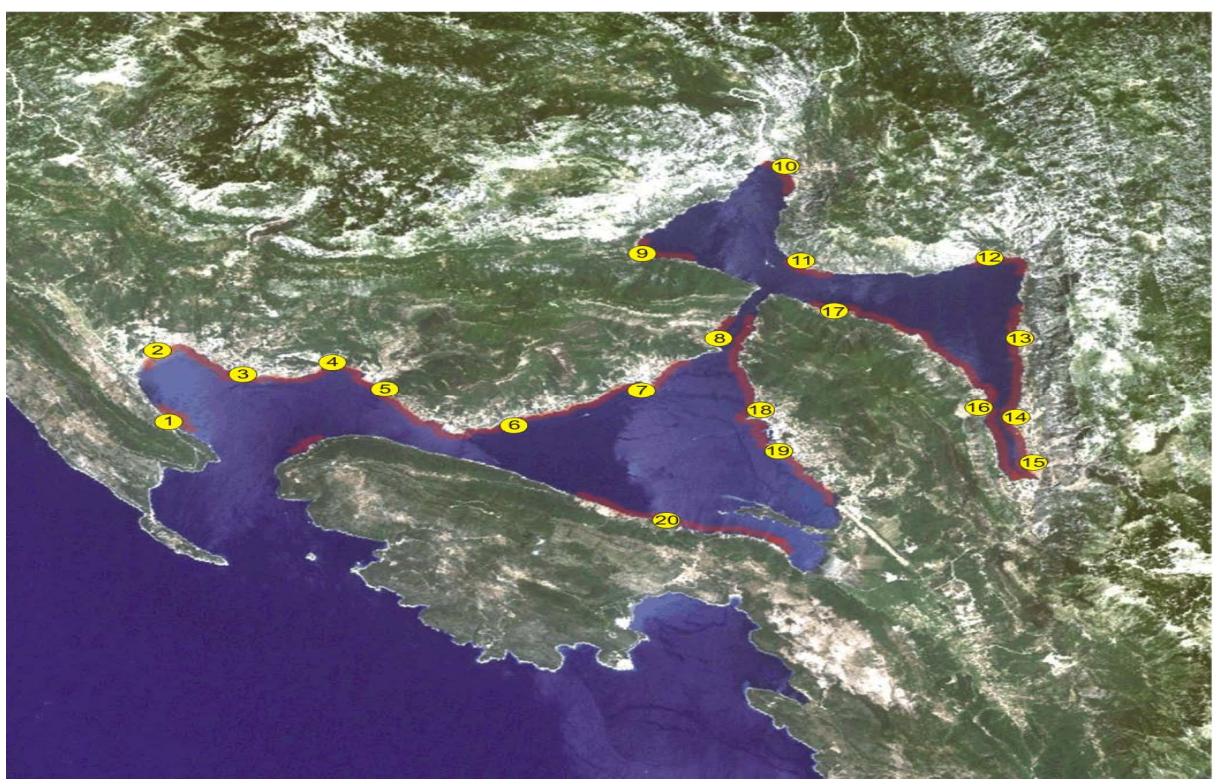

Figure 3 - View of the sites where sea water samples were collected of and the view of the Bay region that are under increasing anthropogenic pollution

Slika 3 - Pregled lokacija na kojima su uzimani uzorci morske vode i prikaz Zalivskih područja koja su pod povećanim antropogenim zagađenjem.

Legend:

(n) Sample locations

The area under the influence of anthropogenic pollution

Legenda:

(D) Mesto uzimanja uzorka

Prostor pod uticajem antropogenog zagađenja 
Table 1

Measurement of nitrate, nitrite and orthophosphate on the locations and time intervals in the observed groups.

Tabela 1

Izmereno stanje azota i fosfora u Zalivu kroz merenje nitrata, nitrita i ortofosfata po lokacijama i vremenskim intervalima u posmatranim grupama.

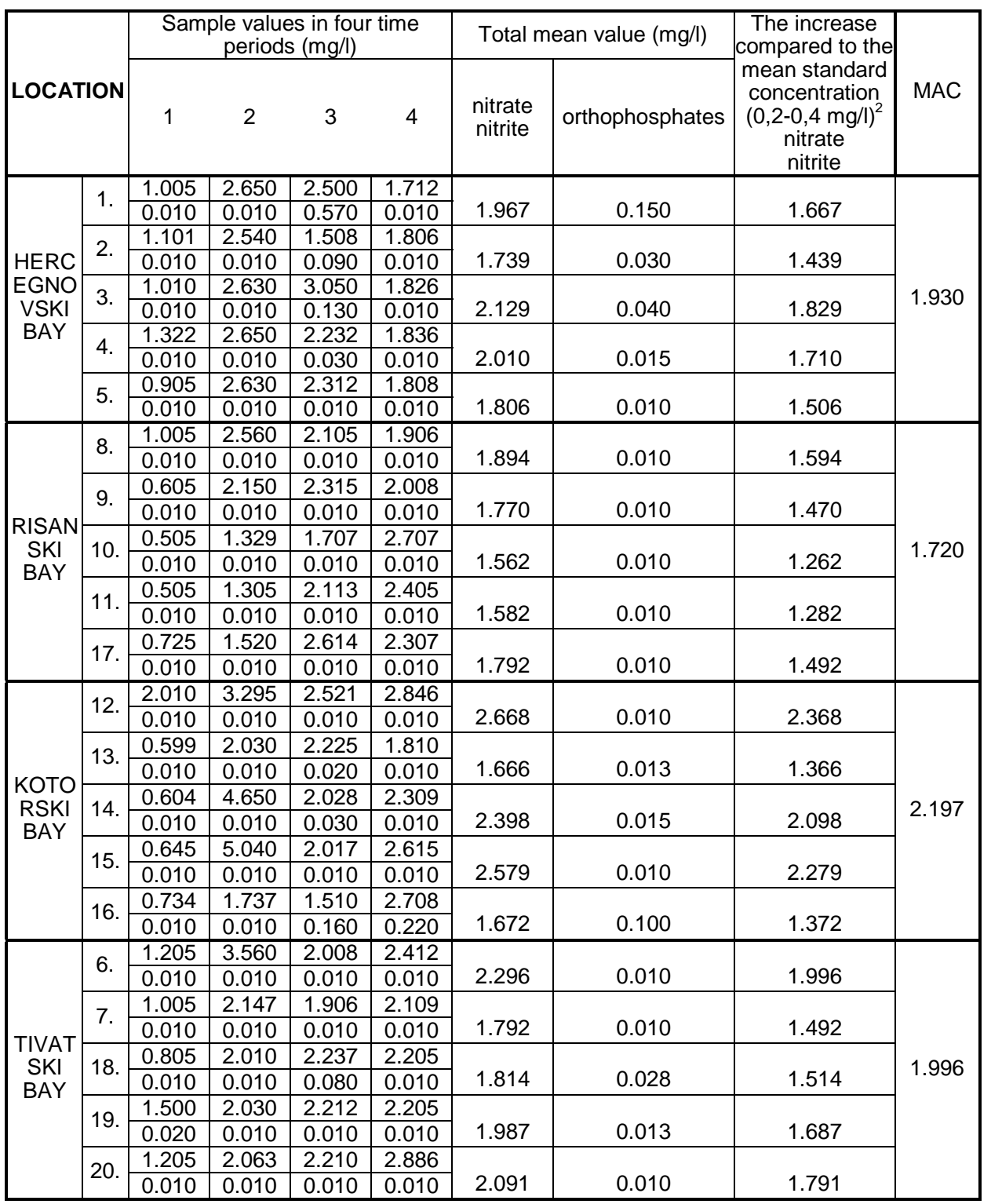

${ }^{2}$ The concentration of nitrogen salts in seawater is 0.2-0. $4 \mathrm{mg} / \mathrm{l}$ (M Jablanovic. et al, 2003). 
Features of the Bay* level measured mean annual concentrations (MAC)

Table 2 nitrate and nitrite

Tabela 2 Karakteristike delova Zaliva* i nivo izmerene srednje godišnje koncentracije (SGK) nitrata i nitrita.

\begin{tabular}{|c|c|c|c|c|}
\hline Characteristics & $\begin{array}{c}\text { Hercegnovski } \\
\text { Bay }\end{array}$ & $\begin{array}{c}\text { Kotorski } \\
\text { Bay }\end{array}$ & $\begin{array}{c}\text { Risanski } \\
\text { Bay }\end{array}$ & Tivatski Bay \\
\hline Bay area $\left(\mathrm{km}^{2}\right)$ & 30.491 & 16.793 & 8.336 & 33.501 \\
\hline $\begin{array}{c}\text { Number of } \\
\text { households/population }\end{array}$ & $11076 / 33034$ & \multicolumn{2}{|c|}{$7290 / 22947$} & $4502 / 13630$ \\
\hline MAC & 1.930 & 2.197 & 1.720 & 1.996 \\
\hline
\end{tabular}

See Figure* 3 for the location of the Bay.

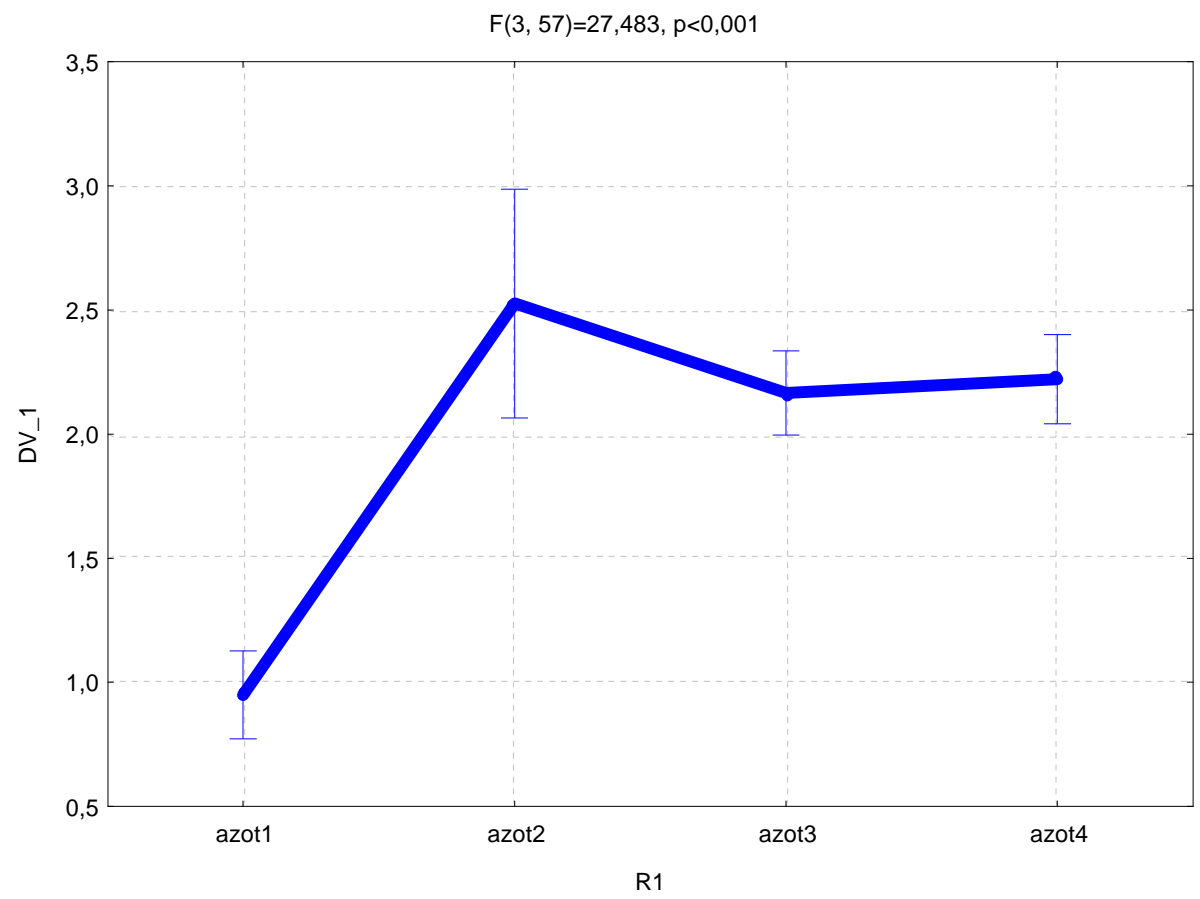

Figure 4 - Displaying high concentration of nitrogen salts, obtained from the measurements in the four periods (spring - nitrogen1, summer x 2 - nitrogen 2,3 and fall - nitrogen4)

Slika 4 - Prikaz srednje koncentracije azotnih soli, dobijene merenjem u četiri vremenska perioda (proleće - azot1, leto x 2 - azot 2,3 i jesen - azot4) 


\section{Risk Characterization}

At this stage of the assessment, the data are integrated through the EAM model, in order to estimate the risk, exposure and ecological effects for the major key points of the assessment, as well as to make final conclusion remarks and describe the results of the risk analysis. This process was conducted similarly to the other known risk assessments, e.g. [10], [3], [4], [5].

The data obtained using the given methodology of environmental risk assessment and management provide a valuable input for various policy makers - managers and local land use planning authorities, giving them a possibility to predict the environmental impact of the particular land use scenarios within the given area and to explore different options that would reduce that impact. These options would also contribute to the reduction of current levels of concentration of nitrogen compounds in the water of the Bay.

For a number of different possible scenarios in the monitoring and environmental management of the Bay, various combinations of models can be used to achieve desired solutions that would restore the quality of water to the level that existed in the previous period (period without increased pollution), as it was done in some similar examples (Waquoit Bay) ${ }^{3}$.

Based on the conducted research, it can be assumed that there is a withdrawal of some sea grass as the "Posidonia oceanica"4 because of its sensitivity to the increased amounts of nitrogen in sea water, decreasing its diffusion rapidly with the nitrogen increase greater than $1.5 \mathrm{mg} / \mathrm{l}$. This type of seaweed and many others will probably disappear entirely if the increase of nitrogen exceeds $3.0 \mathrm{mg} / \mathrm{l}$.

\section{Conclusion}

This project is an example of an ecological risk assessment based on an assessment of current environmental conditions and realistic assumptions of what can happen in the future in that area. The assumption that the Bay is threatened and endangered by the environmental pollution and stressors that constantly contribute to it, especially in summer when their intensity increases, is confirmed and documented within the scope of this project.

The study defined the primary stressor that leads to the occurrence of anthropogenic eutrophication of the Bay. By comparative analysis, ranking and prevalence, the research results can be summarized as follows:

- Nutrients of anthropogenic origin are greatest stressors in the Bay area.

- During the assessment process a model of increasing eutrophication (MIE) was defined, which focuses on monitoring the increased level

\footnotetext{
${ }^{3}$ Read more about the Waquoit Bay watershed ecological risk assessment. Environmental Management: Serveiss et al. (2000) submitted.

${ }^{4}$ Read more about the impact of eutrophication in the sea grass "Posidonia oceanica, processed in the research, which are given in [1], [11] and [8].
} 
of eutrophication by measuring levels of nitrogen salts as a major stressor. The model also served for the assessment of the quantity and concentration of these substances using their correlations with the critical components of the ecosystem - key points.

- The most important product of the environmental risk assessment in the Bay area is the established conceptual model which provides a lot of information to all parties interested in the management of the given problem, especially in terms of perception of stressors and ecological effects caused by them.

- The defined effects of the stressors' impact are reviewed using the analysis of the following parameters: the reduction in population, changes in the physical habitat, loss of habitat, increasing degree of eutrophication, duplication of certain species, turbidity, contamination of fresh water and tissue contamination of aquatic organisms. In the scope of the project, the increased nitrogen concentrations were regarded as an exposure, while the concentrations of nitrates and nitrites in the sea water were treated as the effects of that increase. The analysis showed possible reactions to the increased levels of nitrogen, including a high risk of phytoplankton and zooplankton biomass growth, habitat loss of some sea grass species and some minor risks on the fish population.

- The existing ecological condition of the Bay can be assessed as unfavorable (eutrophic), with the trend of deterioration over the next period, because of constant emissions of non-purificated wastewaters. Such conditions threaten to jeopardize the necessary ecological balance of the Bay as a set of ecosystems, which would favorize some species at the expense of the suppression - marginalization of the others. Furthermore, it was shown that this is already happening for some species in the Bay.

In order to obtain final conclusions about the presence of pollutants (nitrate, nitrite, etc.) and their impact on the eutrophication in the Bay, monitoring and testing of the sea water in the coming period, as well as systematically throughout the year, is highly recommended.

If we consider this statement as a goal, the results of possible future measurements will certainly be a good basis for the establishment of continuous monitoring and management in the protection and improvement of the ecological situation in the Bay. In addition, if we succeed in that and if this research provides at least a small contribution there, our satisfaction will be even greater!

\section{References}

[1] Antolić, B., Špan A., Istraživanja bentoske flore Bokokotorskog zaliva, Biosystematics, Vol. 16, No. 1, Kotor, 1990.

[2] Andrejić M. i dr, Upravljanje projektima po pristupu projekt menadžmenta, Vojnotehnički glasnik (Military Technical Courier), No. 2, Vol. LIX, pp. 158-174, ISSN 0042-8469, UDC 623+355/359, Beograd, 2011., 
[3] Harris, H. J., Wegner, R. B., Harris VA.: A method for assessing environmental risk: A case study of Green Bay, Lake Michigan, USA, Environmental Management 18, 1994.

[4] Houseknecht, C.R.: Ecological risk assessment case study: special review of the granular formulations of carbofuran based on adverse effects on birds. In: A review of ecological assessment case studies from a risk assessment perspective. Washington, DC, Risk Assessment Forum, U.S. Environmental Protection Agency, 1993.

[5] Heck, W. W: Ecological assessment case study: the National Crop Loss Assessment Network. In: A review of ecological assessment case studies from a risk assessment perspective, 1993.

[6] Gržetić, I., Upravljanje rizikom i njegova procena, Rudarsko-geološki fakultet Univerziteta u Beogradu, Beograd, 2002.

[7] Jablanović, M., Jakšić, P. i Kosanović K.: Uvod u ekotoksikologiju, Univerzitet u Prištini, Prirodno-matematički fakultet Kosovska Mitrovica, Kosovska Mitrovica, 2003, pp 420-421.

[8] Mačić, V., Morska cvjetnica Posidonia oceanica u Bokokotorskom zalivu, Zaštita voda, 2002.

[9] Marković, D. i dr, Životna sredina i njena zaštita, Fakultet za primenjenu ekologiju - "Futura", Univerzitet Singidunum, Knjiga I i II, Beograd, 2008.

[10] NRC (National Research Council): Clean coastal waters, Committee on the causes and management of coastal eutrophication, ocean studies board, and water science and technology board, Washington, DC: National Academy Press, 2000.

[11] Panayotidis at al, An important flowering of Posidonia oceanica (L.) Delile in the Saronikos gulf (Aegean sea, Greece) during 1985. Posidonia Newsletter, 2, 1989, pp 23-27.

[12] Serveiss, V. B; Bowen, J. L; Dow, D. at al, Waquoit Bay watershed ecological risk assessment. Environmental Management: submitted, 2000.

[13] Suter, G. W., Ecological risk assessment, Boca Raton, FL: Lewis Publishers, 1993a.

[14] U.S. EPA, Guidelines for ecological risk assessment. EPA/630/R-95/002Fa. Washington, DC, 1998.

[15] U.S. EPA: Framework for ecological risk assessment. EPA/630/R92/001. Office of Water, Washington, DC, 1992a.

\section{PROCENA EKOLOŠKOG RIZIKA U FUNKCIJI ZAŠTITE ŽIVOTNE SREDINE}

OBLAST: geonauke

VRSTA ČLANKA: stručni članak

\section{Sažetak:}

$\cup$ radu je predstavljena primena metodologije procene ekološkog rizika. Metodologija je primenjena na primeru Bokokotorskog zaliva (Zaliv). 
Istraživanjem je razmatrana procena uticaja većeg broja stresora na ekološke komponente Zaliva. Posledice ovih uticaja ispoljene su kroz povećan stepen eutrofikacije vodene sredine $i$ dovode se $u$ vezu sa koncentracijom azotnih jedinjenja (nitrata i nitrita) Konkretna merenja vršena su u 2008. godini.

Istraživanjem je posebno ukazano na značaj razvoja sistema prikupljanja i obrade ekoloških i drugih informacija radi efikasnijeg upravljanja životnom sredinom datog prostora.

Primenjena metodologija procene ekološkog rizika trebalo bi da u naučnom i stručnom pogledu predstavlja doprinos u oblasti zaštite životne sredine,kako kod nas, tako i u svetu.

Uvod

Težište istraživanja je na procesu procene ekološkog rizika. Ukazano je i da se, koristeći se postavljenom metodologijom, može sprovesti postupak procene u konkretnim uslovima. Na taj način upravljanje rizikom može biti pravilno usmereno i da vodi ka smanjenju rizika od zagađenja. Koristeći se postojećim naučnim i drugim saznanjima, razvijen je sopstveni model procene koji može poslužiti kao dobra osnova za neke buduće procene. Sumnja se da je povećanje azotnih soli jedan od najvećih uzroka nastalih problema u vodenoj životnoj sredini (izazvanih antopogenim faktorom), kao što su smanjenje populacije nekih morskih trava. Ova procena rizika, procenjujući i modelišući efekte na značajne ekološke resurse, opisuje kako prevelika količina ovih materija - jedinjenja predstavlja zabrinjavajući stresor u području Zaliva.

Dokumentujući proces analize i modele sličnih istraživanja, došlo se do postupka kojim se može sprovesti ocena rizika od povećanja nitrata i nitrita, kao i do određivanja obima tih problema u poređenju sa drugim stresorima.

Program istraživanja

Sažet pregled programa istraživanja zasnovan je na metodologiji procene ekološkog rizika primenom metodološkog okvira koji je razvila američka agencija za zaštitu životne sredine U.S. EPA.

Prema korišćenom metodološkom okviru (slika 1), procena rizika obuhvatala je proces pripreme - planiranja i tri naučne faze (formulaciju problema, analizu i karakterizaciju rizika).

Planiranje procene

Osnovni element planiranja odnosio se na razvijanje modela povećanja eutrofikacije (MPE model), što je predviđeno da se sprovede kroz fazu analize.

Planiranjem je definisan cilj procene, koji je glasio: „Uspostavljanje i održavanje kvaliteta morske vode i uslova u habitatu Zaliva“, da bi se obezbedio opstanak različitih populacija biljnih $i$ životinjskih vrsta koje žive u vodenoj sredini Zaliva, i obustavio proces degradacije ekoloških resursa u njegovom području. 
Formulacija problema

Nakon sprovedenog planiranja, pristupilo se fazi formulacije problema kao prvoj od tri naučne faze daljeg toka procene.

Uspostavljen je konceptualni model Zaliva (slika 2) što predstavlja najbitniji proizvod ove faze procene. $U$ odnosu na druge poznate modele, ovaj model im je sličan po metodološkom pristupu izrade, ali je u sadržaju i informacijama koje pruža originalan i svojstven za posmatrano područje.

Analiza rizika

U ovoj fazi, kao najsloženijom u ukupnom procesu procene, sprovedena su odgovarajuća merenja i analize stepena izloženosti izabranih ključnih tačaka procene i pratećih ekoloških efekata prema datom stresoru. Rezultati istraživanja potvrđuju prisustvo povećane koncentracije nitrata i nitrita u morskoj vodi (u priobalnom pojasu) u celom prostoru Zaliva, sa jasno definisanim zonama (delovima Zaliva) gde su koncentracije najveće. Dobijeni rezultati srednje godišnje koncentracije nitrata i nitrita daju dosta jasnu sliku ukupnog nivoa eutrofikacije u priobalnim delovima Zaliva, na osnovu čega se može pretpostaviti i nivo eutrofikacije za dublje i od obale udaljenije zone.

\section{Karakterizacija rizika}

$U$ ovoj fazi procene podaci su integrisani kroz nalaze iz MPE modela, sa ciljem da bi se ocenio rizik na ključne tačke procene, izloženost i ekološke efekte, kao i izvođenje zaključaka i opisivanje rezultata analize rizika. Na osnovu sprovedenog istraživanja pretpostavlja se da dolazi do povlačenja nekih morskih trava kao što je „Posidonia oceanica" upravo zbog njene osetljivosti na povećanje količine azota u morskoj vodi, tako da njena rasprostranjenost naglo opada sa povećanjima većim od 1,5 mg/l. Ova vrsta morske trave, a i mnoge druge, verovatno će potpuno nestati ako povećanje azota premaši 3,0 mg/l.

Zaključak

Postavljeni projekat procene ekološkog rizika Zaliva, predstavlja primer koji je zasnovan na proceni sadašnjeg i realnim pretpostavkama budućeg ekološkog stanja. Pretpostavka da je Zalivu pretila i da preti opasnost u ekološkom smislu zagađenja, stresorima koji konstantno doprinose zagađenju, posebno u letnjem periodu godine kada im se intenzitet pojačava, potvrđena je i dokumentovana izradom ovog projekta.

Istraživanjem je definisan primarni stresor koji dovodi do pojave antropogene eutrofikacije Zaliva. Uporednom analizom, rangiranjem, rasprostranjenošću, ispitivanjem intenziteta uticaja više stresora $i$ verovatnoćom povećanja tokom vremena ustanovljeno je da su hranljive materije antropogenog porekla najveći stresor u području Zaliva.

Analizom je utvrđeno da su u sistemu Zaliva verovatne reakcije na povećanje azota, uključujući veliki rizik od povećanja biomase fito- 
planktona i zooplanktona, gubitak staništa nekih morskih trava, srednji i manji rizik na rasprostranjenost ribljih vrsta. Postojeće ekološko stanje Zaliva može se oceniti nepovoljnim (eutrofnim), sa trendom pogoršanja tokom narednog perioda, jer je prisutno konstantno i iz godine $u$ godinu povećano odlaganje, bez prečišćavanja otpadnih voda. $U$ takvim uslovima može doći, a istraživanjem je konstatovano za pojedine vrste da već dolazi, do narušavanja potrebne ekološke ravnoteže Zaliva kao skupa ekosistema, čime se neke vrste favorizuju na račun potiskivanja - marginalizovanja drugih.

Ključne reči: upravljanje rizikom, procena ekološkog rizika, stresor, zagađenje, eutrofikacija.

Datum prijema članka/Paper received on: 12. 09. 2011.

Datum dostavljanja ispravki rukopisa/Manuscript corrections submitted on: 25. 03. 2012.

Datum konačnog prihvatanja članka za objavljivanje/ Paper accepted for publishing on: 27. 03. 2012. 